\title{
FE DE ERRATA
}

\author{
Valentina Figueroa ${ }^{1}$
}

Recibida: 7 marzo 2019

Estimados editores:

Por un error involuntario de uno de los autores, en el artículo de Figueroa et al. DOI 10.4067/S071773562018005001001 (Publicado en línea: 10-junio-2018), del volumen 50 número 4 de Chungara Revista de Antropología Chilena, en la Figura 3 que corresponde a un mapa geológico del sector arqueológico de Collahuasi, donde se señala la ubicación de los sitios arqueológicos, uno de ellos fue desplazado. Solicitamos a Uds. puedan subsanar este error nuestro, aclarando que la localización mostrada del sitio Ujina 9 en la figura referida es incorrecta. El sitio Ujina 9 se ubica también en un intrusivo de granodioritas (K2gy), a unos 800 metros al sureste del sitio Ujina 8. Las coordenadas exactas UTM Datum WGS 84 del sitio Ujina 9 son Lat.N.7683866/Long.E.536348.

\section{Figura original}

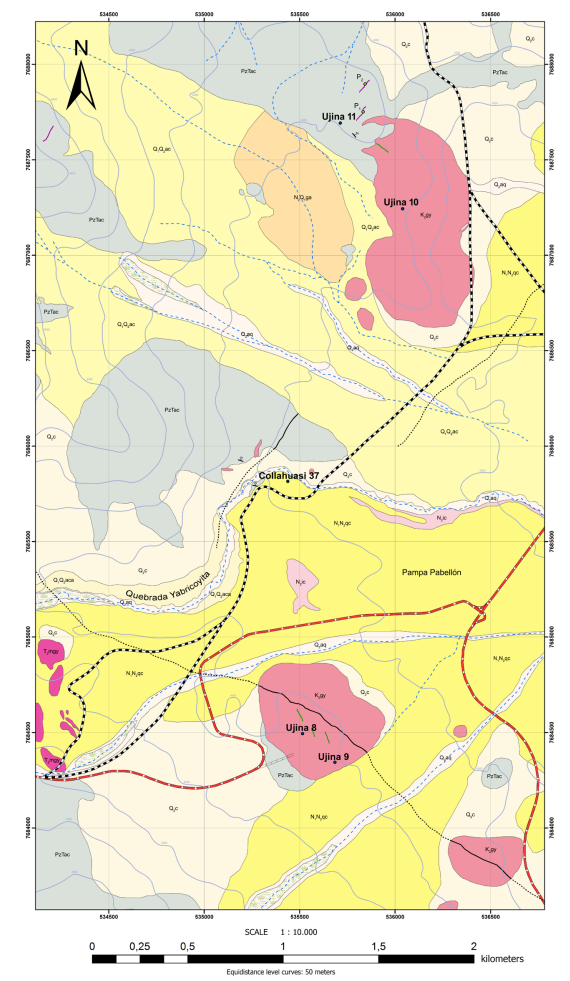

Figure 3. Geological map of the Collahuasi archaeological sector. The archaeological sites are found within three different rock formations, namely PzTac, K2gy y N1N2qc. Site Ujina 11 is found in PzTac (light green), which is a andesitic sequence; Ujina 8, Ujina 9 y Ujina 10 are found in K2gy (orange brown), which is a granodiorite intrusive; and Collahuasi 37 is found in N1N2qc (brown), which is a semiconsolidated clastic deposit. In addition, the P1 and P2 mining shafts have been found in the upper levels of PzTac, running N29E/30SE.

Mapa geológico del sector arqueológico de Collahuasi. Los sitios arqueológicos se encuentran en tres formaciones rocosas diferentes denominadas informalmente como: PzTac, K2gy y N1N2qc. PzTac (verde claro) corresponde a una secuencia de andesitas y sobre esta unidad se ubica el sitio Ujina 11; K2gy (rosado) es un intrusivo de granodioritas y sobre esta unidad se ubican los sitios Ujina 8, Ujina 9 y Ujina 10; y N1N2qc (amarillo) corresponde a depósitos clásticos semiconsolidados modernos y sobre esta unidad se ubica el sitio Collahuasi 37. Además, los piques mineros P1 y P2 se encontraron sobre niveles superiores de la unidad PzTac de dirección N29/30SE.

${ }^{1}$ Instituto de Arqueología y Antropología, Universidad Católica del Norte, San Pedro de Atacama, Chile. vfigueroa@ucn.cl 


\section{Figura corregida}

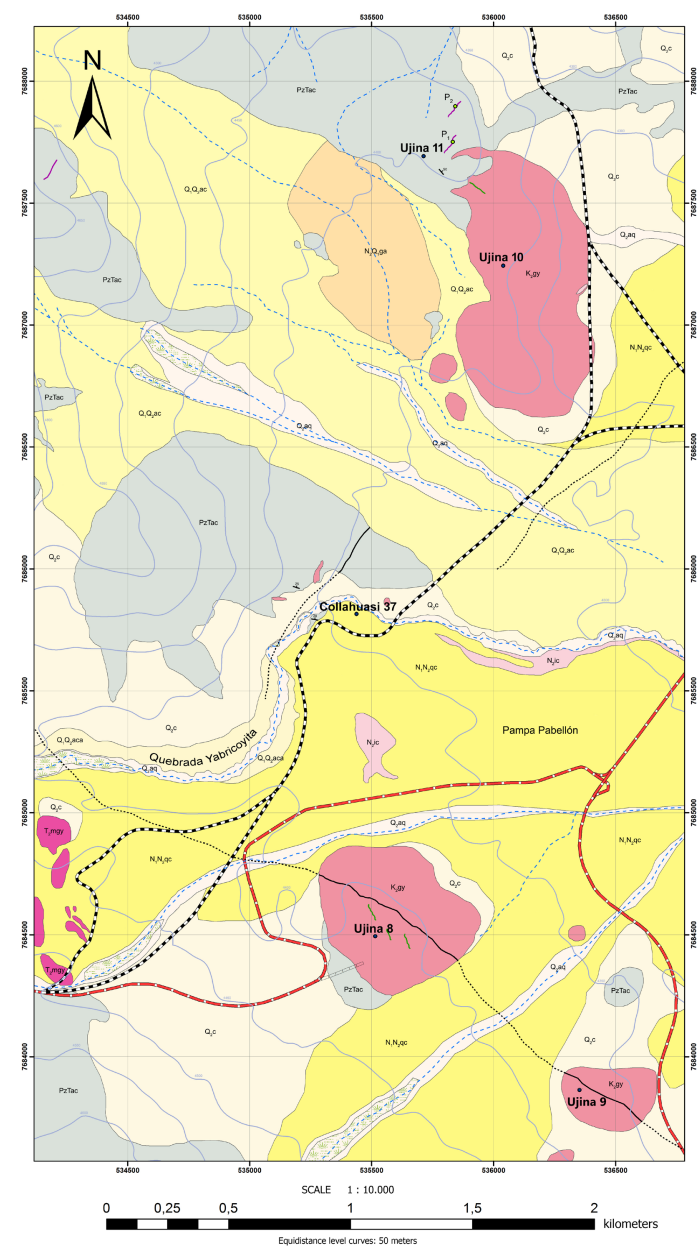

Figure 3. Geological map of the Collahuasi archaeological sector. The archaeological sites are found within three different rock formations, namely PzTac, K2gy y N1N2qc. Site Ujina 11 is found in PzTac (light green), which is an andesitic sequence; Ujina 8, Ujina 9 y Ujina 10 are found in K2gy (orange brown), which is a granodiorite intrusive; and Collahuasi 37 is found in N1N2qc (brown), which is a semiconsolidated clastic deposit. In addition, the P1 and P2 mining shafts have been found in the upper levels of PzTac, running N29E/30SE.

Mapa geológico del sector arqueológico de Collahuasi. Los sitios arqueológicos se encuentran en tres formaciones rocosas diferentes denominadas informalmente como: PzTac, K2gy y N1N2qc. PzTac (verde claro) corresponde a una secuencia de andesitas y sobre esta unidad se ubica el sitio Ujina 11; K2gy (rosado) es un intrusivo de granodioritas y sobre estas unidades se ubican los sitios Ujina 8 , Ujina 9 y Ujina 10; y N1N2qc (amarillo) corresponde a depósitos clásticos semiconsolidados modernos y sobre esta unidad se ubica el sitio Collahuasi 37. Además, los piques mineros P1 y P2 se encontraron sobre niveles superiores de la unidad PzTac de dirección N29/30SE. 